УДК 615.32:616.36:546.26]-018

DOI 10.11603/bmbr.2706-6290.2020.3.11279

\author{
О. Є. Кузів, П. П. Кузів, П. Р. Сельський, А. Т. Телев’як, А. Ф. Слива
}

Тернопільський національний медичний університет імені І. Я. Горбачевського МОЗ Украӥни

\title{
ВПЛИВ АУТОФАГІЇ НА СУБМІКРОСКОПІЧНУ ПЕРЕБУДОВУ ПЕЧІНКИ В ДИНАМІЦІ ХАРЧОВОЇ ДЕПРИВАЦІЇ
}

\section{Вплив аутофрагії на субмікроскопічну перебудову печінки в динаміці харчової депривації}

О. Є. Кузів, П. П. Кузів, П. Р. Сельський, А. Т. Телев'як, А. Ф. Слива

Тернопільський національний медичний університет імені І. Я. Горбачевського МОЗ України

Резюме. Аутофрагія - це внутрішньоклітинна лізосомна деградація і рециркуляція білків й органел для підтримки клітинного та енергетичного гомеостазу.

Мета дослідження - встановити особливості впливу аутофрагії на субмікроскопічну перебудову печінки в динаміці повного голодування (харчової депривації).

Матеріали і методи. Експериментальне дослідження проведене на 30 білих безпородних лабораторних щурах трьохмісячного віку масою тіла 180-200 г. Тварин з експерименту виводили через 1; 3 і 7 діб повного голоду із вільним доступом до води та через 7 діб відновного харчування. Контрольну групу склали 6 щурів. Для проведення ультрамікроскопічного дослідження тканини печінки щурів використовували стандартні методи.

Результати. Повне голодування в експериментальних тварин викликає адаптаційну перебудову гепатоцитів, ступінь вираження якої залежить від терміну експерименту. В перші три доби харчової депривації у гепатоцитах виникають дистрофрічні зміни за різко вираженої гетерогенності ураження часточки й окремих гепатоцитів. Домінуючою структурною ознакою дії повного голодування було різке посилення процесу аутофрасії з редукцією канальців гранулярної ендоплазматичної сітки та гіперплазією агранулярної, збільшення лізосом, пероксисом, аутофрагосом і відсутності гранул глікогену в гепатоцитах. За повного голодування переважає активація репарації над дистрофрічними процесами. На 7-му добу відновленого харчування спостерігається повна реституція печінки при збереженні високої фоункціональної активності клітин Купорера.

Висновки. Відсутність макронутрієнтів високоефективно індукує аутофрагію, яка відіграє провідну роль в структурно-фрункціональній перебудові гепатоцитів у динаміці повного голодування, що проявляється періодом ранніх морфологічних змін, вираженої структурної перебудови, стійкої адаптації та рестиmyчіï.

Ключові слова: щури; харчова депривація; електронно-мікроскопічне дослідження; печінка; аутофрагія.
The autophagy influence on submicroscopic liver restructuring in the dynamics of nutrient deprivation

O. Ye. Kuziv, P. P. Kuziv, P. R. Selskyy, A. T. Televyak, A. F. Slyva

I. Horbachevsky Ternopil National Medical University e-mail: totel@ukr.net

Summary. Autophagy is an intracellular lysosomal degradation and recycling of the proteins and organelles to maintain cellular and energy homeostasis.

The aim of the study - to find the features of autophagy influence on the submicroscopic liver restructuring in the dynamics of complete starvation (nutrient deprivation).

Materials and Methods. The experimental study was performed on 30 white non-pedigree laboratory rats three months of age weighing 180-200 g. Animals were removed from the experiment after 1, 3, and 7 days of complete starvation with free access to water, and after 7 days of restorative nutrition. The control group consisted of 6 rats. Standard methods were used to perform an ultramicroscopic examination of rat liver tissue.

Results. Complete starvation in experimental animals causes adaptive hepatocytes restructuring, the severity of which depends on the duration of the experiment. In the first three days of the nutrient deprivation, there are dystrophic changes in hepatocytes with a pronounced lesion heterogeneity of the lobe and separate hepatocytes. The dominant structural feature of complete starvation was a sharply increased autophagy with a reduction of tubules of granular endoplasmic reticulum and hyperplasia of agranular one, increased lysosomes, peroxisomes, autophagosomes without glycogen granules in hepatocytes. During complete starvation, reparation activation prevails over dystrophic processes. On the 7th day of the restored diet, there is complete restitution of the liver while maintaining the high functional activity of Kupffer cells.

Conclusions. The absence of macronutrients highly effectively induces autophagy, which plays a leading role in the structural and functional restructuring of hepatocytes in the dynamics of complete starvation, which is manifested by a period of early morphological changes, pronounced structural restructuring, stable adaptation and restitution.

Key words: rats; nutrient deprivation; electron microscopy; liver; autophagy. 


\section{ВСТУП}

Аутофрагія - це еволюційний механізм виживання в умовах дефіциту поживних речовин, який полягає у лізосомальній дегідратації і рециркуляції власного вмісту клітини для підтримання клітинного й енергетичного гомеостазу. Термін «аутофагія» (їсти себе) вперше запропонував Крістіан де Дуве більше ніж 40 років тому [1]. Останніми роками науковий світ знову відкрив аутофагію, здійснивши прорив у молекулярне та генетичне розуміння та оцінку фрізіологічного значення цього процесу [2].

Базальна аутофрагія запрограмована в геномі, відбувається в клітині з постійною і низькою швидкістю. Вона $€$ рушійною силою внутрішньоклітинного контролю якості білків і структур цитоплазми (мітохондрій, ендоплазматичного ретикулуму, комплексу Гольджі тощо) шляхом видалення дефектних молекул [3]. Індукована аутофрагія $€$ формою відповіді на розмаїті внутрішні й зовнішні впливи на організм і клітину [4].

Голодування індукує аутофрагію й остання $є$ ключовим компонентом адаптивної реакції клітин і тканин на депривацію, що сприяє виживанню, поки поживні речовини не стануть доступними. Аутолізу перш за все підлягають ушкоджені й менш необхідні для життєдіяльності організму клітинні та тканинні структури [5], розщеплюючи їх лізосоми, сприяють перерозподілу клітинного фонду метаболітів, направленню їх для підтримки найбільш відповідальних життєвих процесів, що демонструє реконструктивну срункцію цих органел [6].

Метою дослідження було виявити особливості впливу аутофрагії на субмікроскопічну перебудову печінки в динаміці повного голодування.

\section{МАТЕРІАЛИ I МЕТОДИ}

Експериментальне дослідження проведене на 30 білих безпородних лабораторних щурах трьохмісячного віку з масою 180-200 г. Тварин із експерименту виводили через 1; 3 і 7 діб повного голоду із вільним доступом до води та через 7 діб відновного харчування. Контрольну групу склали 6 щурів. Для проведення ультрамікроскопічного дослідження тканини печінки щурів використовували стандартні методи. Після отримання біоптату печінки брали 1 мм ${ }^{3}$ тканини та фіксували 2,5 \% розчині глутаральдегіду, потім дофріксовували у $2 \%$ чотириокису осмію. Після зневоднення у розчинах етилового спирту та абсолютного ацетону проби заливали у суміш епоксидних смол (епонаралдит) та полімеризували при $60^{\circ} \mathrm{C}$ протягом 36 год. Ультратонкі зрізи готували на ультрамікротомі LKB-3 (Швеція), потім їх контрастували у сполуках урану і свинцю та вивчали в електронному мікроскопі ПЕМ-125K.
Усі експериментальні дослідження проводилися 3 дотриманням Додатку 4 до «Правил проведення робіт з використанням експериментальних тварин», затверджених наказом МОЗ України № 755 від 12 серпня 1997 року, «Про заходи щодо подальшого вдосконалення організації фрорм роботи 3 використанням експериментальних тварин» та положення «Загальні етичні принципи експериментів на тваринах», ухвалених Першим національним конгресом з біоетики з дотриманням положень Європейської конвенції про захист хребетних тварин, що використовуються для дослідних та інших наукових цілей (Страсбург, 1986).

\section{РЕЗУЛЬТАТИ Й ОБГОВОРЕННЯ}

Електронно-мікроскопічні дослідження, проведені через добу повного голоду, не виявили будь-яких суттєвих змін у формі й величині ядер та ядерець гепатоцитів. Звертало на себе увагу легке розширення перинуклеарного простору ядер гепатоцитів. Мітохондрії центролобулярних клітин дрібні, округлої фооми з електронно-щільним матриксом. У цитоплазмі більшості гепатоцитів проти інтактних різко зменшився вміст зернистої ендоплазматичної сітки, а гладкі мембрани розміщувались групами в декілька паралельних рядів. Проте в окремих гепатоцитах, частіше центролобулярних, мембрани гладкої ендоплазматичної сітки піддавались фррагментації та вакуолізації. Звертає на себе увагу різка гіпертрофія комплексу Гольджі та наростання вмісту первинних лізосом проти контрольної групи (рис. 1, 2).

Найбільш характерним для гепатоцитів тварин, які голодували, є різке посилення процесу аутофрагії. По всій цитоплазмі клітин виявляються множинні вторинні лізосоми аутофрагічного типу, а також залишкові тільця. Збільшення кількості та активності лізосом у гепатоцитах за повного голодування направлене на перерозподіл

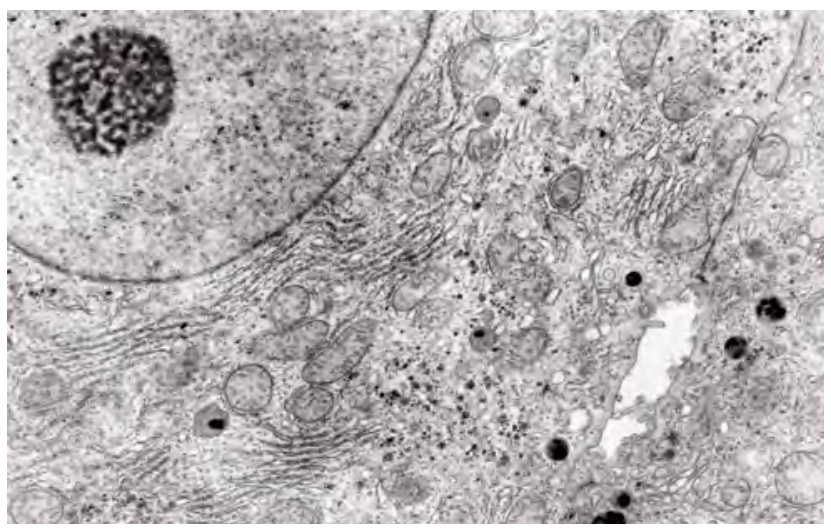

Рис. 1. Ядро, в якому домінує еухроматин. Ядерце сітчастої структури в центрі ядра. Канальці гранулярної та агранулярної ендоплазматичної сітки. Множинні мітохондрії, гранули глікогену і лізосоми рівномірно локалізовані в парануклеарній зоні. Ультраструктура гепатоцита печінки інтактного щура. Електронограма. ×15 000. 


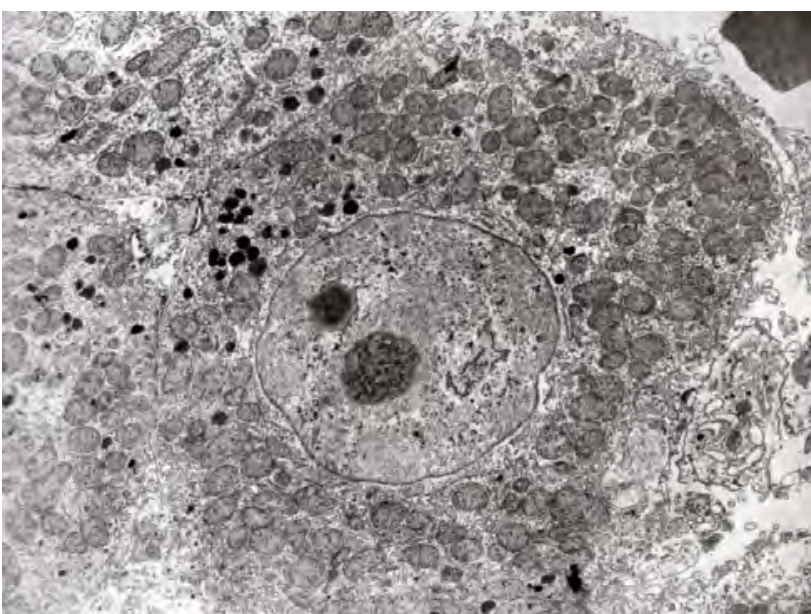

Рис. 2. У цитоплазмі центролобулярного гепатоцита множинні дрібні овальної та округлої фрорми мітохондрії 3 електронно-щільним матриксом. Збільшення канальців агранулярної ендоплазматичної сітки, множинні лізосоми та аутофрагосоми. Печінка щура. 24-годинне повне голодування. Електронограма. $\times 11000$.

внутрішньоклітинних резервів біополімерів різної природи для поповнення клітинного фронду компонентами, необхідними для забезпечення пластичних і фрункціональних потреб [7]. На важливість харчової деривації, як основного чинника активації аутофрагії, вказують L. He et al. [8].

Субмікроскопічні зміни ядер гепатоцитів щурів за повного тридобового голодування свідчили про підвищення їх фрункціональної активності: в нуклеоплазмі домінував еухроматин, виявлялось одне, два, інколи три ядерця сітчастої структури, які, як правило, ектоповані (рис. 3), проте в окремих гепатоцитах за незначних змін з боку органел цитоплазми в ядрі виявляли ліпідні краплі (рис. 4).

У центролобулярних гепатоцитах мітохондрії розміщуються перинуклеарно компактними групами (рис. 5). Вони, зазвичай, великі округлої фрорми, більшість із них 3 електронно-просвітленим матриксом і короткими кристами, в окремих - кристи відсутні. Гранулярна ендоплазматична сітка редукована, агранулярна у вигляді ергастоплазми локалізується в різних ділянках цитоплазми, зростає вміст пероксисом. В окремих клітинах виявляються ліпідні краплі, багато лізосом та великі аутофрагосоми і залишкові тільця контуруються по всій цитоплазмі.

В окремих гепатоцитах (рис. 6) впритул до крапель ліпідів знаходяться мітохондрії. У їхній цитоплазмі виявляються розширені, фррагментовані та вакуолізовані канальці гладкого ретикулуму та гіпертрофовані структурні компоненти комплексу Гольджі з чисельними лізосомами, розмаїтими за величиною аутофагосомами та залишковими тільцями. Гранули глікогену відсутні.

На 7-му добу повного голодування часточкова будова печінки збережена, в ній домінували

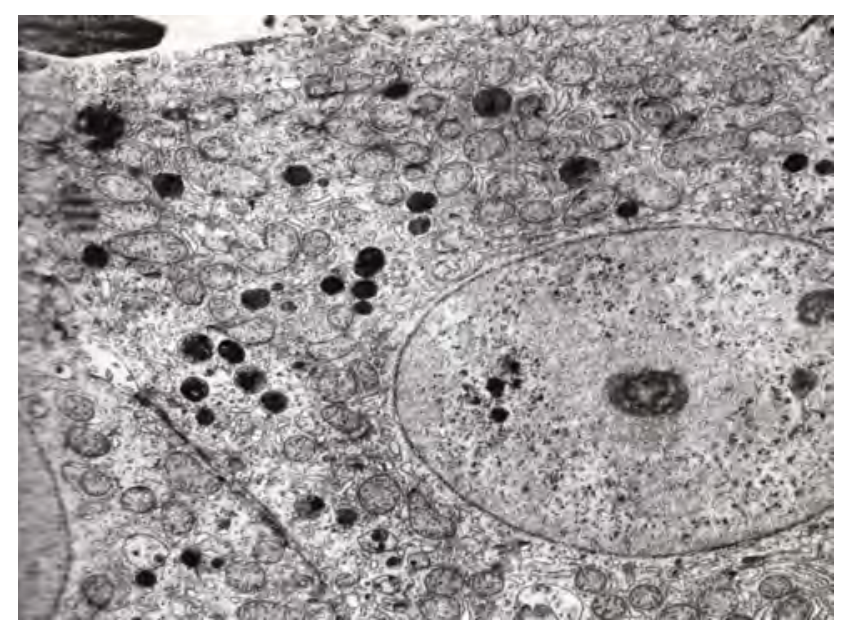

Рис. 3. Ядро овальної форми, в каріоплазмі домінує еухроматин. Ядерце сітчастої структури, ектоповане. У цитоплазмі гепатоцита множинні мітохондрії, розмаїті за фрормою і розмірами. Окремі 3 просвітленим матриксом і редукованими кристами. Множинні лізосоми й аутофагосоми. На васкулярному полюсі клітини дрібні ліпідні краплі. Просвіт жовчного капіляра дещо розширений. Печінка щура. 3-я доба повного голодування. Електронограма. ×16 000.

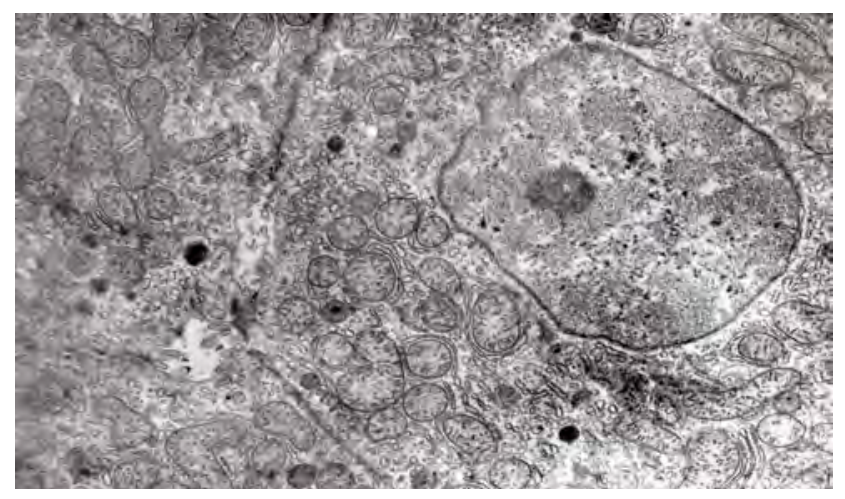

Рис. 4. Ядро округлої форми з ліпідною краплею на периферії каріоплазми. Канальці гранулярної ендоплазматичної сітки щільно контактують із мітохондріями, деякі з них розширені та вакуолізовані. Печінка щура. 3-я доба повного голодування. Електронограма. ×18 000.

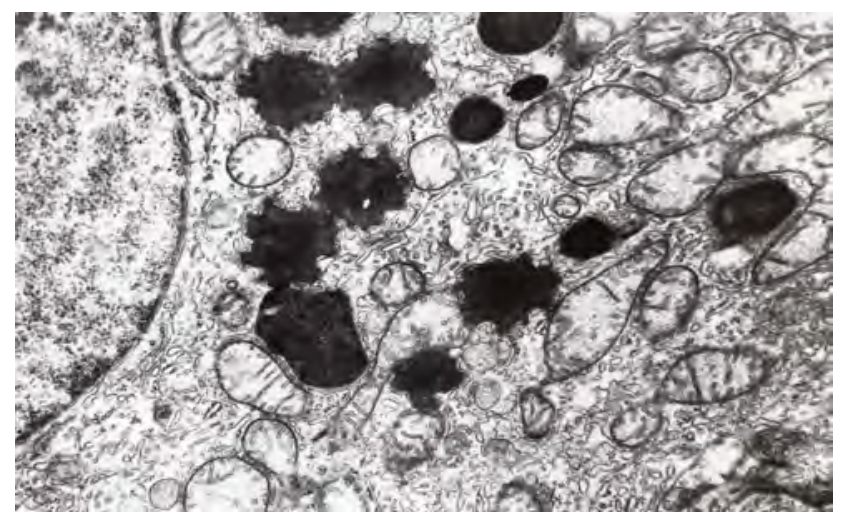

Рис. 5. У цитоплазмі центролобулярних гепатоцитів великі, різної форми компактні групи мітохондрій, ділянки ергастоплазми, численні лізосоми, і різні за величиною аутофрагосоми. Печінка щура. 3-я доба повного голодування. Електронограма. ×24 000.

регенераційні процеси, які характеризувались збільшенням кількості темних клітин, особливо на
ISSN 2706-6282(print)

ISSN 2706-6290(online)
Вісник медичних і біологічних досліджень

Bulletin of Medical and Biological Research
$3(5), 2020$ 


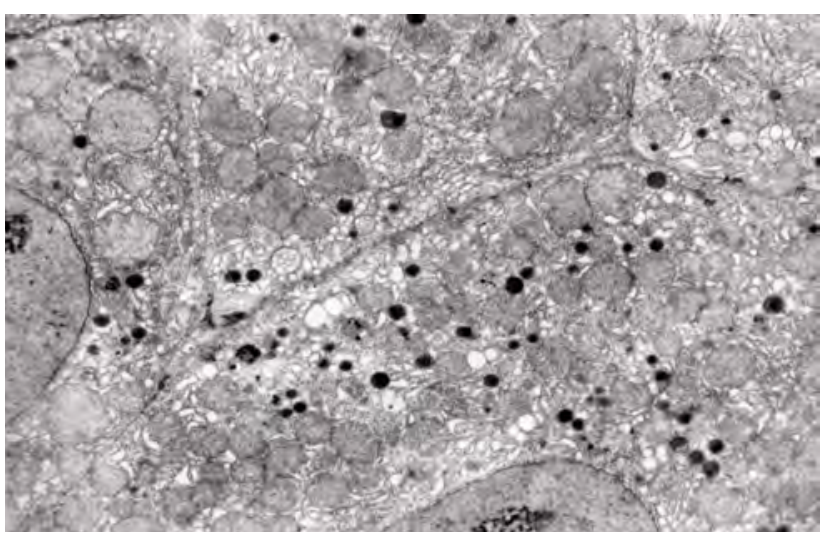

Рис. 6. У цитоплазмі гепатоцитів виявляються ліпідні краплі, розширені, вакуолізовані канальці агранулярної ендоплазматичної сітки та комплексу Гольджі, множинні лізосоми й аутофрагосоми. Печінка щура. 3-я доба повного голодування. Електронограма. ×12 000.

перифрерії часточок. У темних гепатоцитах периферійної ділянки часточки спостерігалися гіперпластичні процеси, які проявлялись збільшенням відносного об'єму гранулярної ендоплазматичної сітки, помірним розширенням її канальців, гіперплазією мітохондрій (рис. 7).

Звертає на себе увагу тісний взаємозв'язок мітохондрій із канальцями гранулярного ретикулуму і структурними елементами комплексу Гольджі. Світлі гепатоцити характеризувались низькою осміофрільністю гіалоплазми, перевагою коротких в окремих місцях вакуолізованих канальців агранулярної ендоплазматичної сітки, поліморфрізмом мітохондрій 3 електронно-помірнощільним мактриксом. Як у світлих, так і в темних гепатоцитах виявляються лізосоми, аутофагосоми і гіпертроорований пластинчастий комплекс Гольджі. На васкулярній поверхні гепатоцитів контуруються чисельні мікроворсинки, які заповнюють простір Діссе, виявляються клітини Купфера з ознакою високої фрункціональної активності.

У гепатоцитах центральної ділянки печінкових часточок спостерігається наявність чисельних мітохондрій з чіткими кристами і помірно осміофрільним мактриксом. В таких гепатоцитах виявляються лише поодинокі лізосоми й аутофрагосоми. Ядра великі, округлої фрорми з рідкими неглибокими інвагінаціями. У каріоплазмі домінує еухроматин, дрібні грудки гетерохроматину зрідка виявляються в каріоплазмі. Як правило, ядерце сітчастої структури одне, хоча може бути і два, ектоповані.

На синусоїдному полюсі гепатоцитів короткі мікроворсинки, гемокапіляри нормальної ультраструктури.

У відновний період (на 7-му добу відновленого харчування) печінка експериментальних тварин за будовою виглядала дещо краще проти печінки інтактних щурів. Структура печінкових часточок була

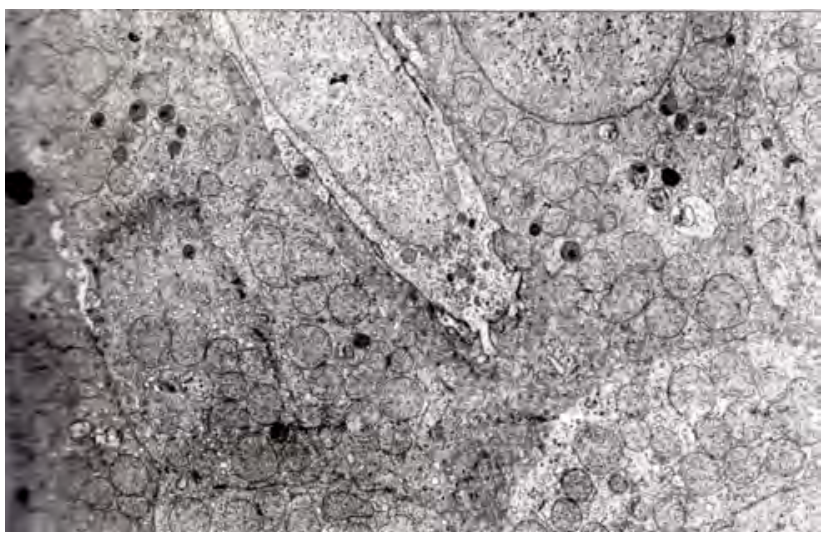

Рис. 7. Субмікроскопічна картина світлого і темного гепатоцитів. 7-ма доба повного голодування. Електронограма. ×12 000.

більш чіткою, краще проглядались контури та ядра гепатоцитів за «чистої» цитоплазми.

Про пріоритетність аутофрагії у структурній перебудові гепатоцитів свідчать дані інших авторів, які підкреслюють її важливість у перебігу фрізіологічних та розвитку патологічних процесів у печінці [9-11].

Таким чином, повне голодування в експериментальних тварин викликає адаптаційну перебудову гепатоцитів, ступінь вираження якої залежить від терміну експерименту. В перші три доби досліду в гепатоцитах виникають дистрофрічні зміни за різко вираженої гетерогенності ураження часточки й окремих гепатоцитів. Домінуючою структурною ознакою дії повного голодування було різке посилення процесу аутофрагії із редукцією канальців гранулярної ендоплазматичної сітки та гіперплазією агранулярної, збільшення лізосом, пероксисом і відсутності гранул глікогену в гепатоцитах. За повного голодування відбувається переважання активації репарації над дистрофрічними процесами. Компенсаторні та реституційні процеси в печінкових часточках починаються із гепатоцитів перипортальної ділянки і поширюються в напрямку до центролобулярних. На 7-му добу відновленого харчування спостерігається повна реституція печінки при збереженні високої фрункціональної активності клітин Купфера.

\section{ВИСНОВКИ}

1. Відсутність макронутрієнтів високоефективно індукує аутофрагію, яка відіграє провідну роль у структурно-фрункціональній перебудові гепатоцитів у динаміці повного голодування.

2. Структурно-орункціональна перебудова печінки за дії повного голодування послідовно проходить період ранніх морорологічних змін, вираженої структурної перебудови, стійкої адаптації та реституції. У перші два періоди різко зростає ау- 
тофрагія та накопичуються дрібні краплі жиру, що разом із редукцією канальців ендоплазматичного ретикулуму та різкого зменшення гранул глікогену до повного зникнення $€$ морфрологічним проявом

\section{СПИСОК ЛІТЕРАТУРИ}

1. De Duve C. Functions of lysosomes / C. De Duve, R. Wattiaux // Annu. Rev. Physiol. - 1966. - Vol. 28. P. 435-492.

2. Regylation mammalian autophagy in physiology and pathophysiology / B. Ravikumar, S. Sarkar, J. Davies [et al.] // Physiol. Rev. - 2010. - Vol. 90. - P. 1383-1435.

3. Eskelinen E. L. Fine structure of the autophagosome / E. L. Eskelinen // Methods Mol. Biol. - 2008. - Vol. 445. P. 11-28.

4. Functions of autophagy in normal and diseased liver / M. J. Czaja, W. X. Ding, T. M. Donohue // Autophagy. 2013. - Vol. 9 (8). - P. 1131-1158.

5. Ефективність корекції тетрахлорметанового гепатозу повним голодуванням // О. $€$ Кузів, О. Й. Бакалюк, Л. Й. Цетнар, О. I Кузів // Український морфологічний альманах. - 2011. - № 3 (9). - С. 155-157.

6. Russell R. C. Autophagy regulation by nutrient signaling / R. C. Russell, H. X. Yuan, K. L. Guan // Cell Res. - 2014. - Vol. 24 (1). - P. 42-57.

\section{REFERENCES}

1. De Duve C., Wattiaux R. Functions of lysosomes. Annu Rev Physiol. 1966;28: 435-492.

2. Ravikumar B, Sarkar S, Davis JE, Futte M, GarciaArencibia M, Green-Thompson ZW, Jimenez-Sanchez M[et al. Regylation mammalian autophagy in physiology and pathophysiology. Physiol. Rev. 2010;90: 1383-435.

3. Eskelinen EL. Fine structure of the autophagosome. Methods Mol Biol. 2008;445: 11-28.

4. Czaja MJ, Ding WH, Donohue TM. Functions of autophagy in normal and diseased liver Autophagy. 2013;9(8): 1131-58.

5. Kuziv OYe, Bakalyuk OY, Tsetnar LY, Kuziv OI. The efficiency of tetrachloromethane hepatosis correction by complete starvation. Ukrainian Morphological Almanac. 2011;3(9): 155-7. Ukrainian. адаптаційної перебудови гепатоцитів, направленої на нормалізацію їх функцій. Процеси репаративної реституції переважають над дистрофрічними в періоди стійкої адаптації та відновлення.

7. Liver autophagy contributes to the maintenance of blood glucose and amino acid levels / J. Ezaki, N. Matsumoto, M. Takeda-Ezaki // Autophagy. - 2011. Vol. 7. - P. 727-736.

8. Autophagy: the last defense against cellular nutritional stress / L. He, J. Zhang, J. Zhao [et al.] // Advances in Nutrition. 2018. - Vol. 9 (4). - P. 493-504.

9. Schneider J. L. Liver autophagy: much more than just taking out the trash / J. L. Schneider, A. M. Cuervo // Nat. Rev. Gastroenterol. Hepatol. - 2014. - Vol. 11 (3). P. 187-200.

10. Calcium/calmodulin-dependent protein kinase IV limits organ damage in hepatic ischemia-reperfusion injury through induction of autophagy / J. Evankovich, R. Zhang, J. S Cardinal // Am. J. Physiol. Gastrointest. Liver Physiol. 2012. - Vol. 303. - P. 189-198.

11. Autophagy in liver diseases / P. E. Rautou, A. Mansouri, D. Lebrec // J. Hepatol. - 2010. - Vol. 53. P. 1123-1134.

6. Russell RC, Yuan HX, Guan KL. Autophagy regulation by nutrient signaling. Cell Res. 2014;24(1): 42-57.

7. Ezaki J, Matsumoto N., Takeda-Ezaki M, et al. Liver autophagy contributes to the maintenance of blood glucose and amino acid levels. Autophagy. 2011;7: 727-36.

8. He L, Zhang J, Zhao J, Ma N, Kim SW, Qiao S, Ma X. Autophagy: The Last Defense against Cellular Nutritional Stress. Advances in Nutrition. 2018;9(4): 493-504.

9. Schneider JL, Cuervo AM. Liver Autophagy: much more than just taking out the trash. Nat Rev Gastroenterol Hepatol. 2014;11(3): 187-200.

10. Evankovich J, Zhang R, Cardinal JS, Zhang L, Chen J, Huang $\mathrm{H}$, Beer-Stolz D et al. Calcium/calmodulindependent protein kinase IV limits organ damage in hepatic ischemia-reperfusion injury through induction of autophagy. Am J Physiol Gastrointest Liver Physiol. 2012;303: 189-98.

11. Rautou PE, Mansouri A, Lebrec D, Durand F, Valla D, Moreau R. Autophagy in liver diseases. J Hepatol. 2010;53: 1123-34. 